\title{
ANALYSING LEADERSHIP TRAITS IN ESTABLISHING EFFECTIVE LEADERSHIP AT ESKOM
}

\author{
J Lekganyane, Eskom \& T Oosthuizen, University of Johannesburg
}

\begin{abstract}
Purpose: Leadership is one of the crucial modern topics in the field of management. A leadership trait is one of the three components to be considered in establishing leadership success. The other two components not assessed in this research are ideal leadership behaviour and situational factors. Managers must act as leaders as they have a critical role to play to ensure effective change. This paper explores the leadership traits relevant to middle managers acting as leaders at Eskom.
\end{abstract}

Design I Methodology I Approach: A theoretical analysis of literature in the field of leadership is conducted with a further focus on leadership traits. Quantitative research is done within Eskom by means of an e-mail survey to a random sample of employees on middle management level. Areas of possible improvement and leadership traits excellence are identified. Recommendations are made regarding leadership traits.

Findings: The broad leadership trait categories tested include: intelligence; flexibility; sensitivity to others; stability; dominance; high energy; integrity (honesty and ethics); and finally locus of control. The most dominant traits based on the perception of the respondents are that they possess integrity, intelligence, high energy and the ability to act as leaders. Leadership traits that require great attention and are not as dominant are sensitivity to others, flexibility and to some extent stability.

Implications: Managers must have the leadership ability and trait to influence employees in order to communicate, direct, negotiate and motivate with success. Teamwork and a relationship of trust are required in the modern and changing organisation in order to be successful in achieving organisational goals.

Originality I Value: South Africa as well as Southern Africa could face an energy crisis in the near future. As Eskom is currently facing growing demand for services and is experiencing limitations to provide this continuous increase in demand, managers need to develop the leadership capacity with the appropriate traits to deal with this increasing threat.

Key words and phrases: leadership, leadership traits, management, Eskom

\section{INTRODUCTION}

Strong leadership is necessary to be able to establish performance direction and to cope with change. A manager should internalise different facets of his/her character in order to handle different people in different situations. An effective manager has to modify, change or adapt his natural character to suit different purposes and conditions (Beer, 1990:11-12). At times, different people make incompatible demands on the manager, creating role conflicts. The extent to which a manager is able to successfully reconcile the divergent demands is related to the manager's effectiveness (Yukl, 1981:172). This is not a new concept and was recognised already in 1981 by some authors such as Yukl.

One of the challenges that every supervisor or manager faces is the task of bringing people together to function as a team. In today's competitive environment, managers need to decide what will enable their team to provide the highest level of quality, customer service or task accomplishment. Although there are rare exceptions, in most situations, the ability to respond to quality and customer service is much stronger when people operate as a team (Stark \& Flaherty, 1999:125). The manager with the ideal leadership traits is needed to ensure a learning environment with strategic direction, ability to cope with change and finally the ability to innovate for excellence (Moran \& Brightman, 2001:66-74 and Potter, 2001:54-58).

This article investigates leadership traits within an energy-providing organisation: Eskom. Considering the objectives of this research, the article considers the problem investigated as essential leadership traits required in order for Eskom to deal with the changing demands in their business environment. The research methodology is indicated as theoretical and empirical. The demarcation of the study 
considers the target research organisation Eskom within the context of leadership. The literature review follows and aims to investigate leadership in order to specifically understand relevant leadership traits for success. Findings of the empirical research are presented, followed by the conclusions and recommendations presented by means of discussion of the implications and also indicating the value of the research.

\section{OBJECTIVES OF THE RESEARCH}

The primary objective of this study is to investigate and establish dominant leadership traits as identified in the Eskom organisational environment.

The secondary objectives include:

- defining leadership as management task and managerial role;

- highlighting the leadership traits that suitable leaders should possess and the manner of distinguishing such leaders;

- establishing the leadership traits that are present within middle management in Eskom and making conclusions and recommendations on managerial leadership traits.

\section{PROBLEM INVESTIGATED}

The greatest failures in a changing environment are detected at human level. There are different ways of driving change, but the lack of the right people will lead to change efforts being flawed. Who are the right people? Who is best to lead, manage and implement the required changes? Certain organisations rely on their human resources for the training and development associated with a change strategy. They then assign the "more important" strategic and planning roles to management and functional teams. In some organisations, people who are in the top leadership positions are directly and intimately involved. In others, change agent and change leader positions are rewards for technical accomplishments for those who achieve or exceed objectives (Bishop, 2000:ix).

South Africa wants to be part of a broader vision in order to claim its share in the global market and leadership in diverse aspects. Managers need to ensure that leadership empowers their organisations to levels of excellence. Corporate management requires a move from second wave management that still reigns in many organisations; to advanced management mindsets presented in third and fourth wave disciplines.

In order to deal with a potential energy crisis, leadership in establishing sustainability is crucial. Eskom managers must have the appropriate leadership traits to deal with future opportunities and threats. This set of ideal leadership traits is not exclusive to top management level only, but should also be present on functional and middle management levels.

\section{RESEARCH METHODOLOGY}

The methodology used to analyse the leadership traits in Eskom is based on questions derived from the issues raised in the problem statement. The need to have applicable leadership traits in an organisation prompted the research project. The theoretical analysis also forms the basis for questionnaire compilation.

The research is based on a literature study comprising current and relevant articles, books and discussion documents. The aim is to establish an understanding of leadership traits as identified by previous researchers and their relevance to Eskom. The empirical analysis is done through a questionnaire. The questionnaire is based on a five point categorical Likert scale as established in the research methodology.

It is important to have a tool to measure abstract concepts. A categorical (rating) scale is used to measure the responses. The categorical scale is chosen over a comparative scale because respondents will score objects without direct reference to other objects. A 5-point Likert intensity scale is used as scale design for the questionnaire due to ease of construction, ease of use and good discriminating ability. The scale consists of a statement expressing either a favourable or 
unfavourable attitude towards the object of interest. Each response is assigned a numerical score to reflect its degree of attitude favourableness. The question groups are found in Annexure A.

The size of the study population is 3080 employees in middle management within all divisions of Eskom. The sample is selected through the random sampling method. The data collected is analysed by way of association between variables. The main focus of the study is middle and line managers who are not primary, but secondary leaders in the organisation. In order to gain sufficiently meaningful information, a sample of no less than $30 \%$ of the group is targeted. A conclusion is drawn from the findings of the responses to the questionnaires. Recommendations are made with regard to enhancing managerial leadership of change.

\section{DEMARCATION OF THE STUDY}

One of the essentials required for managing an organisation is leadership. Managerial leadership has been identified as important and critical to managing organisational change and establishing future sustainability (Bartol \& Martin, 2004:3). It is for this reason that the role of leadership is emphasised. This paper looks into the concept of leadership, the leadership traits supporting effectiveness considering the demands of a modern organisation.

Leadership is a narrower concept than management. Leaders may or may not be managers (Ivancevich \& Matteson, 1996:411). The main purpose of exerting leadership influence is to achieve relevant goals. Leaders attempt to influence individuals or groups to achieve important goals (Ivancevich \& Matteson, 1996:412). Some studies dispute the claim that leadership makes a difference. However, there is plenty of evidence to the effect that leadership can impact performance. Leaders do not always make a difference, but they can and do in multiple cases (Gibson et al., 2000:272).

Eskom is currently exposed to a turbulent business arena with various threats influencing effective service provision and future sustainability. Leadership is needed to ensure that management is able to deal with these threats and ensure future sustainability in service provision. Leadership is a management task needed on all management levels and not only on top management level (Oosthuizen, 2004:28 and Bateman \& Snell, 2006:393). Middle managers in Eskom therefore need to have and further develop their leadership skills in order to provide direction, motivation and effective communication to employees in their various business units. Leadership on middle management level could further support top management in overcoming threats and allow the organisation to achieve its vision and mission statements, and goals. Considering this background, middle management in Eskom is identified as a suitable research subject.

Eskom is the major electricity supplier in South Africa and is involved in various core and non-core business activities, including corporate social investment initiatives. In 2003, Eskom celebrated 80 years of existence. Eskom has received various accolades in terms of awards and acknowledgments such as being the most admired brand in 2004 in South Africa as well as Power Company of the Year granted by the Global Energy Awards in 2001. The current corporate identity and logo was implemented in 2001. The vision and mission statements of the organisation strongly emphasise their citizenship and contribution to South Africa (Eskom A, 2006).

The vision statement of Eskom is:

"Together, building the powerbase for sustainable growth and development."

The mission statement of Eskom is:

"Eskom will grow shareholder value by exceeding the needs of local and foreign customers with energy and related services."

The key competency of Eskom is its ability to develop and manage the entire extended electricity value chain so as to deliver high quality, low cost electricity using low grade and scarce resources (e.g. coal, water) in a challenging business, social, natural and political environment. The following is a succinct description of how the business will be managed, where the focus will be, what distinctive competitive characteristics will be nurtured, and what key policies will be pursued: 
- Focusing on our core business of electricity to maximise shareholder value as well as economic, social and environmental returns.

- "Keeping the lights burning" through optimal utilisation and operation of our asset, resource and skills base.

- Ensuring the sustainability of the business through balanced financial, social and environmental decision making.

- Managing our assets and future capital investments to ensure adequate electricity supply to meet the needs of the South African electricity market.

- Making focused and viable investments elsewhere in Africa to further the aims of NEPAD whilst creating the foundation for a continental business in the long term (Eskom B, 2006).

These broad goals and differentiation factors are based on a set of key competence and are also reflected in Eskom's values. In view of Eskom's strategic intent of "being the pre-eminent of African energy and related services business of global stature", the Management Board has taken a closer look at the culture and values needed to realise this intent.

Eskom is changing its business focus, which calls for a shift in the way Eskom as a business operates, and central to these are strong organisational values. These values will stimulate pride in the work they do, strengthen their professionalism, sharpen their customer satisfaction efforts and get the creative juices flowing (Eskom C, 2006).

\section{LITERATURE REVIEW}

In order to develop a measuring instrument to establish the presence of various leadership traits in existing staff on middle management level, a theoretical understanding of the subject field is required. Leadership is defined and investigated as a crucial component for managerial and organisational success. Furthermore the various leadership traits are identified and discussed. These traits are considered the framework for the empirical research.

\section{Defining and Understanding Leadership}

In every group, one person is often typically more influential than others and is probably called a leader. The management task of leading means stimulating people to be high performers. It is directing, motivating and communicating with employees, individually and in groups. Leadership involves close day-to-day contact with people, helping to guide and inspire them towards achieving team and organisational goals (Bateman \& Snell, 1999:7 and Senge, 2006:1-30).

There are various perceptions of leadership. It is therefore difficult to establish one all-inclusive definition. The leadership role is sometimes perceived as a pure management activity, in other cases it is perceived as synonymous with power and others will describe a leader as the popular person. In this paper, the concept of leadership is considered in the context of manager-leaders in the organisation.

Leadership can be defined as an influence in an organisational setting or situation, the effects of which are meaningful and have a distinct impact on and facilitate the achievement of challenging organisationally relevant goals (Ivancevich \& Matteson, 1996:412 and Northouse, 2000). This definition suggests that a person (a leader) can influence the behaviour of others (Bass, 1990:45). This definition further suggests that any individual, in any position, at any level of the organisation can exert goal-specific influence on others. The ability to influence does not solely emerge from a person's position in the organisation. Leaders can be found everywhere in organisations and they make themselves stand out when, through the application of influence, relevant goals are achieved.

It is important to understand the meaning of a leader and leadership in an organisational context. Lussier (2006:75) and Lussier and Achua (2004:5) define leadership as "the influencing process of leaders and followers to achieve organisational objectives through change". Daft (2005:552) continues to minimise the definition of leadership to: "the ability to influence people toward the attainment of goals." (Daft \& Marcic, 2004:5). Kinicki and Williams (2006:444) adapt their take on this definition as: "Leadership is the ability to influence employees to voluntary pursue organisational goals". 
No one spends much time debating whether managers, administrators or bureaucrats are born or made. Shift the focus to leaders, however, and the issue of natural talent or special gifts becomes central. The debated question is whether leaders are born or made or can leadership be taught (McCall, 1998:109-110). McCall (1998:4) asserts that executive leaders are both born and made, but mostly made. His assertion is based on significant research showing that executives do learn, grow and change over time. The real question is not whether extraordinary people have natural talent, but what happens that allows them to bring that talent to fruition (Briscoe \& Hall, 1999:37-52).

Effective leaders are not simply born or made; they are born with some leadership ability and develop it. Whatever a person's leadership ability is, a person can develop his leadership skills (Lussier \& Achua, 2004:9).

With today's focus on teamwork, leadership ability is important to everyone in the organisation, not just managers. The definition of leadership does not suggest that influencing employees is the task of the manager alone; employees influence others. Anyone can be a leader within any group or department (Lussier, 1998:213).

Leaders are important in a variety of organisational settings (Kets, 2001:1-40). Organisations would be less efficient without leaders and, in extreme cases, would be unable to accomplish purposeful goals (Ivancevich \& Matteson, 1996:411). Leadership skills can be developed to be used in personal and professional life as leader and follower (Lussier \& Achua, 2004:20).

Considering the importance and relevance of leadership in order to ensure managerial and organisational success, leadership needs to be further analysed. The following section investigates leadership traits as the focus area for investigating which primary leadership traits, contributing to success, can be identified. The discussion on traits identifies and integrates various findings based on previous research. It is not necessarily an all-inclusive list of leadership traits.

\section{Leadership Traits}

Many studies have concluded that leaders and leadership are important. As such, an interest arose in what sets apart individuals who become leaders from those who do not. This has led to an interest in the distinctive traits of leadership (Gibson et al., 2000:273). Although modern research clearly states that traits are not the only factor, this paper does not disregard the impact and importance of leadership behaviour as well as situational factors.

In the trait theory of leadership, characteristics of leaders have been studied. This approach assumes that a finite number of individual traits of effective leaders could be found. Although some studies have reported that these traits contribute to leadership success, leadership success is however neither primarily nor completely a function of these or other traits (Gibson et al., 2000:275).

Traits that have been identified include:

Dominance: Successful leaders want to be managers and to take charge. However, they are not overly bossy and do not use a bullying style (Lussier \& Achua, 2004:37 and Bateman \& Snell, 1999:411).

High energy: Leaders have the drive and work hard to achieve goals. They have enthusiasm and do not give up. They have a high tolerance for frustration as they strive to overcome obstacles through preparation. They take initiative to bring about improvements rather than ask permission (Lussier \& Achua, 2004:38 and Bateman \& Snell, 1999:411).

Self-confidence: Leaders display self-assurance about their abilities and foster confidence among followers. Self-confidence influences individual goals, efforts and task persistence. Without strong self-confidence, leaders are less likely to attempt to influence followers to take on difficult tasks and to set challenging objectives for themselves and followers (Lussier \& Achua, 2004:38-39 and Gibson et al., 2000:274-275).

Locus of control: Locus of control is on a continuum between external and internal belief in control over one's destiny. Externalisers believe that they have no control over their fate and that their 
behaviour has little to do with their performance. Internalisers (leaders) believe that they control their fate, that their behaviour directly affects their performance. Leaders take responsibility for who they are, for their behaviour and performance and for the performance of their organisational unit (Lussier \& Achua, 2004:39 and Robert \& Achua, 2001:39).

Stability: Stability is associated with managerial effectiveness and advancement. Stable leaders are emotionally in control of themselves, secure and positive. Effective leaders have a good understanding of their own strengths and weaknesses. They are oriented towards self-improvement rather than being defensive. This relates to effective leaders knowing when to lead and when to follow. They compensate for weaknesses by letting others with the strength lead in those areas (Lussier \& Achua, 2004:39 and Robert \& Achua, 2001:39).

Integrity: Integrity refers to behaviour that is honest and ethical, making a person trustworthy. Trustworthiness is an important part of business success. Followers must trust the leader. Unless one is perceived to be trustworthy, it would be difficult to retain the loyalty of followers or to obtain cooperation and support from peers and superiors (Lussier \& Achua, 2004:40 and Ivancevich \& Matteson, 1996:415).

Intelligence: Leaders generally have above-average intelligence. Intelligence refers to cognitive ability to think critically, to solve problems and make decisions. However, intuition, also called hidden intelligence, is important to leadership success (Lussier \& Achua, 2004:40 and Oosthuizen, 2004:83).

Flexibility: Flexibility refers to the ability to adjust to different situations. Leaders need to stay ahead of the immense changes in the world and the pace of change. Without flexibility, leaders would be successful only in limited situations that fit their style of leadership. (Lussier \& Achua, 2004:41 and DuBrin, 1997:189).

Sensitivity to others: Sensitivity to others refers to understanding group members as individuals, what their position on issues is and how best to communicate with and influence them. To be sensitive to others requires empathy and the ability to place oneself in another person's position, to see things from others' point of view (Lussier \& Achua, 2004:41 and Robert \& Achua, 2001:41).

Abilities: Effective leaders share certain abilities and skills that enable them to do their job, although the exact importance of a particular ability cannot be known with certainty. Some of the more important abilities associated with leadership effectiveness include the ability to get along with people who embrace persuasiveness, tact and diplomacy. The effective leader must display more than passing technical knowledge relevant to the task undertaken by the followers (Gibson et al., 2000:274).

Motivation: Leaders seem to exhibit a relatively high need for power, but they act on that need in socially acceptable ways. Effective leaders work within the system to accomplish socially desirable outcomes. Another motivation that sets leaders apart is a relatively high need for achievement (Gibson et al., 2000:275).

Through investigating research as presented by the above-mentioned researchers and authors, eleven primary leadership traits are identified. These traits are indicated as being relevant for success (Thornton, 2004). The eleven traits discussed are used to compile the measuring instrument by formulating questions. Questions measure to what extent these leadership traits are present to ensure success in Eskom.

\section{FINDINGS}

The survey response consists of 980 incumbents and the response rate is $21.5 \%$. The respondents' perception is that they as middle managers have leadership capability and embrace change and innovation. The middle managers believe they have some power and leadership traits to enable them to do their work and influence other employees. These traits as assessed in the questionnaire are analysed in order to establish which traits are relevant or not to the target group. Table 1 illustrates the respondents' perception of the leadership traits that they possess. This factor is reliable as it measures 0.806 on Cronbach's alpha, which exceeds the minimum norm of 0.7 . 
Table 1: Reliability leadership: traits

\begin{tabular}{|r|r|}
\hline \multicolumn{2}{|c|}{ Reliability Statistics } \\
\hline Cronbach's Alpha & $\mathrm{N}$ of Items \\
\hline .806 & 14 \\
\hline
\end{tabular}

The respondents possess a broad base of leadership traits. The dominant traits based on the respondents' feedback are integrity, intelligence and high energy. Integrity is the trait that was listed as a high priority by the respondents. This indicates that middle managers value integrity within Eskom. High energy and ability were also rated highly. High energy is required by leaders to cope within demanding situations and changing environments. The ability to complete tasks and be creative and innovate in a particular environment assists with a middle manager's ability to cope with problems and to make use of opportunities. Minimising error is essential and continuous improvement of staff's ability to do a job is therefore necessary. The organisation must continue efforts to maintain these traits at a high level in order to realise effective leadership of change. Agreement with statements reflecting on the core leadership characteristics exceeded an $80 \%$ support of the relevant statements. Dealing with complexity resulted in $90 \%$ or more respondents confirming this leadership ability and trait. Current threats in the Eskom business environment demand the leadership trait to cope with complexity, considering a high technological business environment.

The traits that are rated low are sensitivity to others and confidence. The respondents indicated low sensitivity to other employees, which can reflect on teamwork. Teamwork demands leadership traits that support sensitivity as well as confidence. A lack in confidence can result in team members not having a trust relationship with their manager acting in a leadership capacity. Limited ability to control or influence employee's emotions was noted (41.9\%). This interaction with supporters or subordinates is crucial in leadership effectiveness. An interactive approach is needed to ensure team success. Confidence in dealing with conditions of uncertainty was rated below other traits at $64.9 \%$. Although the result in general is not negative, this trait appears not to be of importance to middle managers compared to the others and can therefore be improved. Confidence to cope with change is needed and also demanded in an environment requiring continuous improvement.

The traits tested include: intelligence; flexibility; sensitivity to others; stability; dominance; high energy; integrity (honesty and ethics); and finally locus of control. The general perception the respondents have is that they possess the following traits, presented in sequence of relevance:

- Integrity: $99 \%$

- Intelligence: 93,58\%

- High energy: $86,85 \%$

- Ability: $81,4 \%$

- Locus of self control: $81,2 \%$

- Self-confidence: $78 \%$

- Stability: $70,8 \%$

- Flexibility: $64,9 \%$

- Sensitivity to other: $41,9 \%$

It is important to ensure that, even if a manager possesses any or most of the above-mentioned leadership traits, they continuously develop all of them. A changing situation as well as the abilities and maturity of employees (followers) demand the ability to adapt these traits for the given situation. Table 2 is a summary of the relevant statements indicating the response based on the fourteen question statements assessing the existence of leadership traits amongst middle manager leaders at Eskom. 
Table 2: Leadership traits

\begin{tabular}{|c|c|c|c|c|c|c|c|}
\hline & & $\begin{array}{l}\text { Strongly } \\
\text { Disagree }\end{array}$ & Disagree & Neutral & Agree & $\begin{array}{l}\text { Stongly } \\
\text { Agree }\end{array}$ & Total \\
\hline \multirow{2}{*}{$\begin{array}{l}\text { I have the ability to } \\
\text { understand complex issues }\end{array}$} & Count & & & 8 & 128 & 72 & 208 \\
\hline & $\%$ & & & $3.8 \%$ & $61.5 \%$ & $34.6 \%$ & $100.0 \%$ \\
\hline \multirow{2}{*}{$\begin{array}{l}\text { My ability to understand } \\
\text { complex issues enables me to } \\
\text { make decisions }\end{array}$} & Count & & 2 & 15 & 116 & 77 & 210 \\
\hline & $\%$ & & $1.0 \%$ & $7.1 \%$ & $55.2 \%$ & $36.7 \%$ & $100.0 \%$ \\
\hline \multirow{2}{*}{$\begin{array}{l}\text { My ability to understand } \\
\text { complex issues enables me to } \\
\text { solve problems }\end{array}$} & Count & & & 11 & 120 & 79 & 210 \\
\hline & $\%$ & & & $5.2 \%$ & $57.1 \%$ & $37.6 \%$ & $100.0 \%$ \\
\hline \multirow{2}{*}{$\begin{array}{l}\text { My ability to understand } \\
\text { complex issues enables me to } \\
\text { utilise opportunities }\end{array}$} & Count & 1 & & 22 & 125 & 62 & 210 \\
\hline & $\%$ & $.5 \%$ & & $10.5 \%$ & $59.5 \%$ & $29.5 \%$ & $100.0 \%$ \\
\hline \multirow{2}{*}{$\begin{array}{l}\text { I have the ability to make } \\
\text { quality decisions }\end{array}$} & Count & & & 8 & 135 & 66 & 209 \\
\hline & $\%$ & & & $3.8 \%$ & $64.6 \%$ & $31.6 \%$ & $100.0 \%$ \\
\hline \multirow{2}{*}{$\begin{array}{l}\text { I continuously create ways to } \\
\text { increase efficiency in my } \\
\text { workplace }\end{array}$} & Count & & & 39 & 112 & 56 & 207 \\
\hline & $\%$ & & & $18.8 \%$ & $54.1 \%$ & $27.1 \%$ & $100.0 \%$ \\
\hline \multirow{2}{*}{$\begin{array}{l}\text { I have the ability to control } \\
\text { employee's emotions }\end{array}$} & Count & 10 & 29 & 83 & 71 & 17 & 210 \\
\hline & $\%$ & $4.8 \%$ & $13.8 \%$ & $39.5 \%$ & $33.8 \%$ & $8.1 \%$ & $100.0 \%$ \\
\hline \multirow{2}{*}{$\begin{array}{l}\text { I sometimes act selfishly and } \\
\text { do not admit to making a } \\
\text { mistake }\end{array}$} & Count & 52 & 96 & 45 & 13 & 3 & 209 \\
\hline & $\%$ & $24.9 \%$ & $45.9 \%$ & $21.5 \%$ & $6.2 \%$ & $1.4 \%$ & $100.0 \%$ \\
\hline \multirow{2}{*}{$\begin{array}{l}\text { I influence employees in order } \\
\text { to achieve set objectives }\end{array}$} & Count & 2 & 7 & 33 & 138 & 29 & 209 \\
\hline & $\%$ & $1.0 \%$ & $3.3 \%$ & $15.8 \%$ & $66.0 \%$ & $13.9 \%$ & $100.0 \%$ \\
\hline \multirow{2}{*}{$\begin{array}{l}\text { I influence employees to } \\
\text { persist under difficult } \\
\text { complex conditions }\end{array}$} & Count & 2 & 3 & 34 & 138 & 33 & 210 \\
\hline & $\%$ & $1.0 \%$ & $1.4 \%$ & $16.2 \%$ & $65.7 \%$ & $15.7 \%$ & $100.0 \%$ \\
\hline \multirow{2}{*}{$\begin{array}{l}\text { I am able to handle high } \\
\text { demands when taking } \\
\text { responsibility }\end{array}$} & Count & & 3 & 10 & 130 & 67 & 210 \\
\hline & $\%$ & & $1.4 \%$ & $4.8 \%$ & $61.9 \%$ & $31.9 \%$ & $100.0 \%$ \\
\hline \multirow{2}{*}{ I act ethically in my work } & Count & & & 2 & 56 & 152 & 210 \\
\hline & $\%$ & & & $1.0 \%$ & $26.7 \%$ & $72.4 \%$ & $100.0 \%$ \\
\hline \multirow{2}{*}{$\begin{array}{l}\text { I make difficult decisions in } \\
\text { my work }\end{array}$} & Count & 1 & 2 & 42 & 97 & 63 & 205 \\
\hline & $\%$ & $.5 \%$ & $1.0 \%$ & $20.5 \%$ & $47.3 \%$ & $30.7 \%$ & $100.0 \%$ \\
\hline \multirow{2}{*}{$\begin{array}{l}\text { I do not deal with conditions } \\
\text { of uncertainty well in my work }\end{array}$} & Count & 37 & 98 & 42 & 25 & 6 & 208 \\
\hline & $\%$ & $17.8 \%$ & $47.1 \%$ & $20.2 \%$ & $12.0 \%$ & $2.9 \%$ & $100.0 \%$ \\
\hline
\end{tabular}

\section{IMPLICATIONS}

For middle managers that manage people, consideration should be given to their influence on issues relating to hiring, rewarding, promoting, punishing and dismissal of employees. A manager could be allowed to give input into hiring, rewarding, promoting, punishing and dismissal of subordinates and a senior manager makes the final decision. This would give the managers some power to influence the behaviour of employees. Managers must have the leadership ability and trait to influence employees in order to communicate, direct, negotiate and motivate with success. Without such power, it would be difficult to influence employees because they know that, despite their performance, the manager's 
view does not count on issues relating to reward power. Teamwork is required in the modern organisation and a management team that is not able to act sensitively towards their human resources will have limited success in achieving organisational goals. Establishing a relationship of trust with employees is needed to ensure effective team performance as well as the ability to cope with changing and threatening business environments.

Matching the right combination of leadership traits, considering the required behaviour as well as the relevant situational factors is crucial. Further research could be undertaken to determine whether the leadership style is chosen according to the situation and, if not, educate the managers about the different styles and how to choose a suitable style, considering appropriated traits and required behaviour.

Training and development is recommended. This must establish a competence within managers to maintain a balance between relations with people and getting the job done. Relations with people are as important as getting the job done and the two should not be considered mutually exclusive. Should relations with people and getting the job done be considered to be mutually exclusive, change would not happen or be smooth as the leadership may not be effective.

\section{ORIGINALITY AND VALUE OF RESEARCH}

South Africa as well as Southern Africa could face an energy crisis in the near future. As Eskom is currently facing growing demand for services and is experiencing limitations to provide in this era of continuous increase in demand, managers need to develop the leadership capacity to deal with this increasing threat. The energy environment is continuously exposed to change and the current threat is certainly a change that demands strong and effective leadership throughout the organisation. Leadership needs to be fostered on all management levels in order to move this energy empire in a direction that will enable all units to increasingly improve their ability to deliver services. Establishing the existing bases of leadership traits is unique research within Eskom. Knowledge of existing leadership traits and the need in developing it further could empower a large proportion of management within the bigger organisation.

\section{CONCLUSION}

Considering the tempo of change and the impact of change on any organisation, the need for leaders in managerial positions to be flexible is becoming increasingly important. As Eskom is continuously exposed to change and possible new crises in this industry are looming, the ability of flexible leaders to deal with change is of utmost importance. It is therefore essential to develop these skills in order to establish the appropriate trait on this management level.

Managers are directly and interactively involved with employees, therefore their leadership ability demands sensitivity to others. This people orientation is essential in order to influence and motivate employees. Acceptable levels of performance are greatly dependant on this human interaction and understanding. Diversity management training can assist in acquiring the necessary skills in dealing with people and their individual human needs in the workplace.

Leadership is certainly a skill that needs development on all management levels. Leadership is crucial for strategic implication on top management level but furthermore requires leadership on management level in a team-based work environment. Leadership and managers with the relevant traits are required to ensure adaptability, innovation and direction for Eskom. These traits as discussed should not be seen in isolation but need to be supported by the relevant leadership behaviour and contextualised in the relevant situation.

\section{REFERENCES}

Bateman TS \& Snell SA. 1999. Management, Building Competitive Advantage. Boston: McGraw-Hill.

Bateman TS \& Snell SA. 2006. Leading and collaborating in a competitive world. USA: McGraw-Hill International.

Bartol KM \& Martin DC. 2004. Management. $4^{\text {th }}$ ed. Boston: Irwin McGraw-Hill. 
Bass BM. 1990. Bass and Stodgill's Handbook of Leadership. New York: Free.

Beer M. 1990. Lead to Succeed. London: Mercury Books Division.

Bishop CH. 2001. Making Change Happen One Person at a Time: Assessing Change Capacity within your Organisation. New York: AMACOM.

Briscoe JP \& Hall DT. 1999. Grooming and picking: Leaders using competency frameworks: Do they work? Organisational Dynamics, Autumn:37-52.

Daft RL. 2005. The leadership experience. $3^{\text {rd }}$ ed. Canada: Thomson South Western.

Daft RL \& Marcic D. 2004. Understanding Management. $4^{\text {th }}$ ed. USA: Thomson South Western.

DuBrin AJ. 1997. Fundamentals of Organisational Behavior - An Applied Approach. Cincinnati: South Western College Publishing.

Eskom A. 2006. [Online] Available from: http://www.eskom.co.za/heritage/eskom_1990.htm [Accessed: 14/03/2006].

Eskom B. 2006. [Online] Available from: http://www.eskom.co.za/live/content.php?Category_ID=58 [Accessed: 14/03/2006].

Eskom C. 2006. [Online] Available from: http://www.eskom.co.za/live/content.php?Category_ID=25 [Accessed: 14/03/2006].

Gibson JL, Ivancevich JM \& Donelly Jr JH. 2000. Organisations - Behaviour Structure Processes. Boston: Irwin McGraw-Hill.

Hellriegel D, Jackson SE, Slocum J, Staude G, Amos T, Klopper HB, Louw L \& Oosthuizen TFJ. 2005. Management. $2^{\text {nd }}$ South African Ed. Cape Town: Oxford University Press.

Ivancevich JM \& Matteson MT. 1996. Organisational Behaviour and Management. $4^{\text {th }}$ ed. Boston: Irwin, McGraw Hill.

Kets de Vries MFR. 2001. The Leadership Mystique - a user's manual for the human enterprise. Harlow: Pearson Education Limited.

Kinicki A \& Williams BK. 2006. Management: a practical introduction. Boston: McGrawHill Irwin.

Kotter JP. 1996. Leading change. Boston: Harvard Business School Press.

Krause DG. 1997. The Way of the Leader. London: Nicholas Brealey Publishing Limited.

Lussier RN. 1998. Human Relations in Organisations: Application and Skill Building. $4^{\text {th }}$ ed. Boston: Irwin McGraw Hill.

Lussier RN \& Achua CF. 2004. Leadership theory, application and skill development. $2^{\text {nd }}$ ed. USA: Thomson South Western.

Lussier RN. 2006. Management Fundamentals: Concepts, Applications, Skill Development. $3^{\text {rd }}$ ed. Cincinnati: South Western College Publishing.

McCall Jr MW. 1998. High Flyers - Developing the Next Generation of Leaders. Boston: Harvard Business School Press.

Moran JW \& Brightman BK. 2000. Leading organisational change. Journal of Workplace Learning: employee counseling today, 12(2):66-74.

Northouse PG. 2000. Leadership theory and practice. $2^{\text {nd }}$ ed. Thousand Oaks: Sage. 
Oosthuizen TFJ. 2004. Management Tasks for managerial success. $2^{\text {nd }}$ ed. Johannesburg: FVBC.

Potter J. 2001. Creating a passion for change: the art of intelligent leadership. Industrial and Commercial Training, 33(2):54-58.

Robert NL \& Achua CF. 2001. Leadership-Theory-Application-Skill Development. Cincinnati: SouthWestern College Publishing.

Senge PM. 2006. The fifth discipline: The art and practice of the learning organisation. New York: Doubleday Currency.

Stark PB \& Flaherty J. 1999. The Manager's Pocket Guide to Leadership Skills. Canada: HRD Press Inc.

Thornton PB. (n.d.) Leadership Helping People to Succeed [Online] Available from: http://home.att.net/ nicolej/leadershipart.htm [Accessed: 18/08/2004].

YukI GA. 1981. Leadership in Organisations. Englewood Cliffs, New Jersey: Prentice-Hall Inc.

\section{ANNEXURE A}

\section{Question Group: Leadership Traits}

- I have the ability to understand complex issues.

- My ability to understand complex issues enables me to make decisions.

- My ability to understand complex issues enables me to solve problems.

- My ability to understand complex issues enables me to utilise opportunities.

- I have the ability to make quality decisions.

- I continuously create ways to increase efficiency in my workplace.

- I have the ability to control employees' emotions.

- I sometimes act selfishly and do not admit to making a mistake.

- I influence employees in order to achieve set objectives.

- I influence employees to persist under difficult or complex conditions.

- I am able to handle high demands when taking responsibility.

- I act ethically in my work.

- I make difficult decisions in my work.

- I do not deal with conditions of uncertainty well in my work. 